\title{
Contamination and Pollution Studies of Heavy Metals in Sand Filter Media Waste Dumpsite in Yenagoa, Bayelsa State, Nigeria
}

\author{
1*IKOKO, IL; ${ }^{2}$ OSU, CI; ${ }^{2}$ HORSFALL, M \\ *l Bayelsa State Ministry of Water Resources, Isaac Boro Expressway, Okaka, Yenagoa, Bayelsa State, Nigeria \\ ${ }^{2}$ Department of Pure \& Industrial Chemistry, University of Port Harcourt, Choba, Port Harcourt, Nigeria \\ *Corresponding Author Email: ifiemiikoko@gmail.com; Tel: +234803671 3260, +234 7058628765
}

\begin{abstract}
The contamination and pollution level of five Heavy Metals in spent Sand Filter Media [SFM] waste dumpsite was investigated to ascertain the contamination, pollution and possible migration in that environment. Samples were collected at the surface, $0.1 \mathrm{~m}$ depth and $100 \mathrm{~m}$ away from the dumpsite and analysed using Flame Atomic Absorption Spectrophotometer (FAAS) for concentration of $\mathrm{Cr}, \mathrm{Fe}, \mathrm{Mn}$. $\mathrm{Ni}$ and $\mathrm{Pb}$ ions. Geochemical Pollution Indices were used to evaluate the contamination and pollution level of the HMs comparatively using the world shale average values and the experimental control value. Results obtained showed highest concentration of $12.50 \mathrm{mg} / \mathrm{kg}$ for Fe and lowest detectable concentration of $0.2 \mathrm{mg} / \mathrm{kg}$ for $\mathrm{Ni}$ at the top of the dumpsite. All five heavy metals had low concentrations compared to WHO and national standards for soil quality both at the top and $0.1 \mathrm{~m}$ depth of the dumpsite. Percentage concentrations of the heavy metals at the top showed $78.81,12.04,7.88,1.26 \%$ in the order $\mathrm{Fe} \gg>>\mathrm{Cr}>\mathrm{Mn}>\mathrm{Ni}>\mathrm{Pb}$ with the values of $\mathrm{Ni}$ and $\mathrm{Cr}$ at $0.1 \mathrm{~m}$ depth slightly higher indicating some level of migration. Contamination Factor $\mathrm{C}_{\mathrm{f}}$, depicts very severe contamination to slight pollution at the top with minimum of 0.714 and maximum of 1.471. Degree of Contamination $\mathrm{C}_{\mathrm{d}}$, of $<8$ and Modified Degree of Contamination $\mathrm{mC}_{\mathrm{d}}<1.5$ showed low contamination. The pollution load index, PLI values of $<50$ depicts that no drastic rectification measure was needed which concludes that the SFM dumpsite was contaminated but technically not polluted.
\end{abstract}

DOI: https://dx.doi.org/10.4314/jasem.v24i4.6

Copyright: Copyright $(2020$ Ikoko et al. This is an open access article distributed under the Creative Commons Attribution License (CCL), which permits unrestricted use, distribution, and reproduction in any medium, provided the original work is properly cited.

Dates: Received: 11 February 2020; Revised: 16 March 2020; Accepted: 26 March 2020

Keywords: Surface mobility, Yenagoa, heavy metal contamination, Pollution indices, Bayelsa State

The surface mobility, biochemical redox reactions and underground bioaccumulation of heavy metal contaminants and their related impact in the ecosystem is of considerable concern to chemists and other environmentalists around the world (Leizou et al., 2015). Among the underground water contaminants, heavy metals are known to be of most concern to environmentalists because their compounds (ligands) are indeed still in reaction and are capable of many more reactions while the central metals are relatively inert and can accumulate from small quantities to quite larger quantities (Dube, et al. 2001). Further environmental concern of HM contaminants reported by $\mathrm{Wu}$ et al (2012), are due to their prolonged persistent stay in the environment unchanged, their ability to be recycled biochemically in the same form that they were, their ability to accumulate and increase their concentration biologically, their biological toxicity to flora and fauna, their capability to undergo reduction \& oxidation reactions with or without availability of oxygen, their ability to undergo precipitation, solubilisation, to aggregate or flocculate in solutions, the ability of their ligands to undergo chelation and finally their ability to put all the above together and be toxic in nature (Ademeroti 1996).

Specifically, compounds of $\mathrm{Cr}$ in both oxidation states $\left(\mathrm{Cr}^{3+}, \mathrm{Cr}^{6+}\right)$ are biologically harmful to living things, carcinogenic and damage digestive systems (Fawell et al., 2003). High concentrations of $\mathrm{Mn}$ cause hallucination to even forgetfulness and it affects both flora and fauna and the cause of dark colouration to water and pipings ( $\mathrm{Du}$, et al. 2011). $\mathrm{Ni}$ is carcinogenic at high concentrations and inhalation is known to cause severe lung cancer or nasal tumours as it can replace $\mathrm{Zn}$ and $\mathrm{Mg}$ ions in DNA-polymerase (Fawell, et al. 2007). $\mathrm{Pb}$ is transported through intake and carried by the haemoglobin in blood and is therefore poisonous to man and can even transfer into foetus through umbilical cord. $\mathrm{Pb}$ even at small dosages is known to cause adverse mental situations (Cotruvo, et al. 2011). In addition, water treatment chemicals are also a huge sources of HMs and contributors to reaction byproducts that lead to health risk (Stoddart and Gagnon 2015). The process of water purification using SFM requires aluminium sulphate powder (alum) and chlorine gas or powdered sodium hypoclorite HTH as chemical enhancement (Mustafa and Yusuf 2012)). Depending on $\mathrm{pH}$ and temperature, sedimentation/flocculation processes produces $\mathrm{Al}^{3+}$, $\mathrm{Fe}^{2+}, 3^{+}$by-products of organic and inorganic anions (Sielechi, et al, 2010). Disinfection process effectively produces hypochlorous acid with other significant carcinogenic organic by-products like trihalomethanes [THM], haloacetic acids, etc, while ozone disinfectant produces harmful by-products as well (WHO 2011). 
The substance of this study, Sand Filter Media [SFM], is commonest, cheapest means and most widely used in water filtration and it is still the best option in developing countries (Lynn et al., 2013). The SFM accumulate these heavy metal and other contaminants to an extent that the filtration is no longer effective and it is removed from the filter vessels into a dumpsite and the filter vessels are recharged (Cakmakci et al., 2009). Studies on trace metals from different areas including the niger delta area of Nigeria, showed HM contamination (Nariman and Mohammed, 2011, Babagana et al., 2014).

This paper reveals studies carried out to show the concentration level of selected heavy metals adsorbed in the SFM dumpsite and the environmental concern upon evaluation with standard pollution indices. In this part of the world, more attention is focused on environmental degradation activities and wastes mainly from oil exploration, and manufacturing activities with minimal attention on the waste from essential public facilities (municipal water producing or health facilities), since these are mostly government infrastructures. However, several works on waste dumpsites mostly showed significant enrichment and pollution (Li and Feng 2012). Although, a few have reported minimal contamination as well (AmosTantua et al., 2014).

\section{MATERIALS AND METHODS}

Study Area: The study city, Yenagoa, is the capital city of Bayelsa State, Nigeria and lies between latitude $4^{\circ}$ $50^{\prime}$ to $5^{\circ} 00^{\prime}$ North and longitude $6^{\circ} 11^{\prime}$ to $6^{\circ} 25^{\prime}$ East. The city is located in a humid tropical wetland area with mean annual rainfall of about $2539 \mathrm{~mm}$ and an average mean temperature of $26.2^{\circ} \mathrm{C}$ (Ayolagha, 2001). The SFM dumpsite that is studied is the Ovom Waterworks located at Geographic Positioning System [GPS] 4.934245,6.266297 interpreted to read 4'56'03.3'’N 6 15 '58.7'’E.

Sampling: Three distinct soil samples were obtained. Sample $\mathrm{A}_{\mathrm{TM}}$ was $2 \mathrm{~kg}$ deposit of Sand-Filter-Media [SFM] collected on the surface of the dumpsite between $0-10 \mathrm{~cm}$ at five (5) different points in the sample location using a soil auger. Half of these were put separately in a black plastic bag, labelled sample $\mathrm{A}_{\mathrm{TM}} 1,2-5$, stored in a cool place for digestion. The other half of the five portions were mixed together to get a representative sample of the entire top surface of the SFM dumpsite and put into a plastic bag, labelled as Sample $\mathrm{A}_{\mathrm{TM}}$ and stored in a cool place. Sample B was collected at a depth of $100 \mathrm{~cm}$ in a $100 \mathrm{~cm} \times 100 \mathrm{~cm}$ x $200 \mathrm{~cm}$ vertical hole dug with a shovel down the centre of SFM dumpsite. Four separate samples were collected after the $100 \mathrm{~cm}$ marked depth at the four corners of the $100 \mathrm{~cm} \times 100 \mathrm{~cm} \times 200 \mathrm{~cm}$ hand-dug hole. The collected four samples from the four-corners were mixed together to get a representative sample at $100 \mathrm{~cm}$ depth and $1 \mathrm{~kg}$ of the representatively mixed sample was put into a plastic bag and stored in a cool place and labelled Sample B. Sample C was collected at surface of the top soil of an unoccupied land space at a distance of about $100 \mathrm{~m}$ away from the SFM dumpsite, as a control sample. About excess of $1 \mathrm{~kg}$ of each sample was collected, stored in a cool place. All the samples were analysed within 48 hours of sampling.

Sample Preparations: Sample digestion was done using standard procedure for acid digestion (APHA 1992). Portions of Samples $A_{T M} 1-5, A_{T M}, B$ and $C$ were each separately mixed thoroughly in the bag, airdried openly for about 5 hours and then sieved to remove the larger coarse particles. $1 \mathrm{~g}$ of each of the samples was measured and put into $150 \mathrm{ml}$ crucible and a 1:2:2 mixture of $5 \mathrm{ml}$ of concentrated nitric acid $\left(\mathrm{HNO}_{3}, 70 \% \mathrm{w} / \mathrm{w}\right)$, with $10 \mathrm{ml}$ of hyperchloric acid $\left(\mathrm{HClO}_{4}, 60 \% \mathrm{w} / \mathrm{w}\right)$ and $10 \mathrm{ml}$ of Hydrofloric acid (HF, $40 \% \mathrm{w} / \mathrm{w}$ ) was added. The mixture was digested in a hot plate in a fume cupboard for 3 hours at about $80^{\circ} \mathrm{C}$ (Leizou et al., 201. The mixture was allowed to cool and $10 \mathrm{ml}$ of distilled water was added to the digest and filtered into $100 \mathrm{ml}$ volumetric flask. The digested mixture was made up to $100 \mathrm{ml}$ by adding deionized water. The digested mixture was then transferred to a $15 \mathrm{ml}$ sample bottle and labelled $\mathrm{A}_{\mathrm{TM}} 1$. The same procedure was used for samples $\mathrm{A}_{\mathrm{TM}} 2-5$, sample $B$ and control sample $\mathrm{C}$ and these are now re-labelled as Атм2, Атм3, Атм4, Атм5, A-TM, B-TM and C-TM. Analysis of the heavy metals concentration for lead $(\mathrm{Pb})$, Iron (Fe), Nickel (Ni), Chromium (Cr) and Manganese (Mn) was done using a Buck Scientific 210 VGP Flame Atomic Absorption Spectrophotometer AAS following prescribed procedures by the manufacturers.

\section{RESULTS AND DISCUSSION}

Results obtained from the analysis done for selected five selected HMs is showed in table 1. Statistical Evaluations: Evaluation of relationship of results using calculations of the Pearson's Correlation Coefficient is given as thus;

$$
\mathrm{r}=\frac{\sum d_{A} d_{B}}{\sqrt{\sum d_{A}^{2} \sum d_{B}^{2}}}
$$

Where, $\mathrm{r}=$ Correlation Coefficient, $\mathrm{d}_{\mathrm{A}}$ and $\mathrm{d}_{\mathrm{B}}$ are concentration results at the sample points $\mathrm{A}$ and $\mathrm{B}$. Calculated Correlation Coefficient, $\mathrm{r}$ is 0.9959611. Correlation Coefficient, r, was read in the standard table with $\mathrm{n}=3$ [being 2 less than the 5 heavy metals as variables considered] are 0.991 at probability of $0.001,0.959$ at probability of 0.01 , and 0.878 at probability of 0.05 . For correlation to be significant, the calculated $r$ value should exceed the tabulated $r$ value. The calculated Correlation Coefficient, $r$, is higher than the tabulated values at all probabilities. This implies that the correlation in the results at the top and $100 \mathrm{~cm}$ depth below the SFM waste dumpsites show significant correlation (Horsfall 2014). 
Table 1. Summary of Analysis

\begin{tabular}{|c|c|c|c|c|c|c|}
\hline $\mathrm{S} / \mathrm{N}$ & Sample ID & $\begin{array}{l}\mathrm{Pb}, \\
{[\mathrm{mg} / \mathrm{kg}]}\end{array}$ & $\begin{array}{l}\mathrm{Fe}, \\
{[\mathrm{mg} / \mathrm{kg}]}\end{array}$ & $\begin{array}{l}\mathrm{Ni}, \\
{[\mathrm{mg} / \mathrm{kg}]}\end{array}$ & $\begin{array}{l}\mathrm{Cr}, \\
{[\mathrm{mg} / \mathrm{kg}]}\end{array}$ & $\begin{array}{l}\mathrm{Mn}, \\
{[\mathrm{mg} / \mathrm{kg}]}\end{array}$ \\
\hline $\mathrm{i}$ & Sample $\mathrm{A}_{\mathrm{TM}}-1$ & 0.00 & 12.49 & 0.21 & 1.93 & 1.26 \\
\hline ii & Sample $A_{T M}-2$ & 0.00 & 12.52 & 0.20 & 1.90 & 1.24 \\
\hline iii & Sample $A_{\mathrm{TM}}-3$ & 0.00 & 12.48 & 0.19 & 1.89 & 1.24 \\
\hline iv & Sample $A_{\mathrm{TM}}-4$ & 0.00 & 12.52 & 0.20 & 1.92 & 1.27 \\
\hline \multirow[t]{3}{*}{$\mathrm{v}$} & Sample $A_{\mathrm{TM}}-5$ & 0.00 & 12.48 & 0.20 & 1.91 & 1.25 \\
\hline & Mean $A_{T M 1: 5}$ & 0.00 & 12.50 & 0.20 & 1.91 & 1.25 \\
\hline & Std. Dev. $A_{T M: 5}$ & 0.000 & 0.018 & 0.006 & 0.014 & 0.012 \\
\hline 1 & Sample $A_{\mathrm{TM}}$ & 0 & 12.5 & 0.2 & 1.91 & 1.25 \\
\hline 2 & Sample B ${ }_{\mathrm{TM}}$ & 0 & 12.3 & 0.29 & 2.14 & 0.28 \\
\hline 3 & Sample C $\mathrm{TM}$ & 0 & 12.1 & 0.28 & 2.29 & 0.85 \\
\hline
\end{tabular}

Table 2. Total HM concentration in Samples $A_{T M}, B_{T M}$ and $C_{T M}$

\begin{tabular}{|c|c|c|c|c|c|c|}
\hline $\mathrm{S} / \mathrm{N}$ & SAMPLE ID & {$[\mathrm{Pb}]$} & {$[\mathrm{Fe}]$} & {$[\mathrm{Ni}]$} & {$[\mathrm{Cr}]$} & {$[\mathrm{Mn}]$} \\
\hline \multirow[t]{2}{*}{ A } & Sample $A_{T M}[\mathrm{mg} / \mathrm{kg}]$ & 0.00 & 12.50 & 0.20 & 1.91 & 1.25 \\
\hline & Sample $\mathrm{A}_{\mathrm{TM}}[\%]$ & $0.00 \%$ & $78.81 \%$ & $1.26 \%$ & 12.06 & 7.88 \\
\hline \multirow[t]{2}{*}{ B } & Sample B & 0.00 & 12.30 & 0.29 & 2.41 & 0.28 \\
\hline & Sample $\mathrm{B}_{\mathrm{TM}}[\%]$ & $0.00 \%$ & $81.95 \%$ & $1.93 \%$ & $14.26 \%$ & $1.87 \%$ \\
\hline \multirow[t]{2}{*}{$\mathrm{C}$} & Sample $\mathrm{C}_{\mathrm{TM}}[\mathrm{mg} / \mathrm{kg}]$ & 0.00 & 12.10 & 0.28 & 2.29 & 0.85 \\
\hline & Sample $\mathrm{C}_{\mathrm{TM}}[\%]$ & $0.00 \%$ & $77.96 \%$ & $1.80 \%$ & $14.76 \%$ & $5.48 \%$ \\
\hline
\end{tabular}

Total Heavy Metals Concentration: Comparative evaluation of the concentrations of the selected HMs from the three (3) different sampling points is given in Table 2. The results showed high Fe concentration which was possibly due to the Fe content of the underground water in the Niger Delta area (Agbalagba, et al. 2011). The lowest concentration of $\mathrm{HM}$ was $\mathrm{Ni}$ which was $0.20 \mathrm{mg} / \mathrm{kg}$ while $\mathrm{Pb}$ was undetected in the samples. The percentage concentration of the five metals in the top of the SFM shows that Fe had $78.81 \%$ of the total concentration followed by Cr with $12.04 \%$, Mn with $7.88 \%$, Ni with $1.26 \%$ and $\mathrm{Pb}$ with undetected concentration. The percentage concentration in Sample $\mathrm{B}_{\mathrm{TM}}, 100 \mathrm{~cm}$ below the surface, reveals that $\mathrm{Fe}$ increased to $81.95 \%$ of the total metal concentration, $\mathrm{Cr}$ increased to $14.26 \%$, Mn decreased to $1.87 \%$, Ni increased to $1.93 \%$ while $\mathrm{Pb}$ was undetected. This increase can be attributed to the migration of the HMs from the surface down the SFM dumpsite may be due to seepage, run off and metals bound to exchangeable and carbonate fractions that are relatively looser (Beltran, et al. 2010). The sample $\mathrm{C}_{\mathrm{TM}}$, from $100 \mathrm{~m}$ away, gave the concentration of $\mathrm{Fe}$ as highest being $77.96 \%$, while $\mathrm{Cr}$ was 14.76 , Mn was $5.48 \%$, Ni was
$1.80 \%$ and $\mathrm{Pb}$ again was undetected. A comprehensive look at the results of the total metal concentration at the three points [top, below and away] from the SFM reveals the trend below:

Sample $\mathrm{A}_{\mathrm{TM}}$ - Top SFM: $\mathrm{Fe}>>>\mathrm{Cr}>\mathrm{Mn}>\mathrm{Ni}>\mathrm{Pb}$ Sample $\mathrm{B}_{\mathrm{TM}}-100 \mathrm{~cm}$ below: $\quad \mathrm{Fe}>>\mathrm{Cr}>\mathrm{Mn}$ $>\mathrm{Ni}>\mathrm{Pb}$

Sample $\mathrm{C}_{\mathrm{T} \mathrm{M}^{-}}$100m away: $\mathrm{Fe}>>\mathrm{Cr}>\mathrm{Mn}>\mathrm{Ni}>\mathrm{Pb}$

Geochemical Indices: Geoaccumulation Index, Igeo, is used to determine the level of contamination of heavy metals in soils essentially for recognizing and managing soil pollution. It is expressed as;

$$
I_{\text {geo }}=\log _{2} \frac{C_{n}}{1.5 B_{n}}
$$

Where $C_{n}=$ measured conc. of element in the sediment or soil, $B_{n}=$ geochemical background value, and $1.5=$ constant to analyse fluctuations in the environment.

The result of the Geoaccumulation Index, $\mathrm{I}_{\text {geo, }}$, is expressed in USA, Europe and Nigeria as comparative of seven grades as given in table 3 .

Table 3. $I_{g e o}$ Classes and contamination level [Muller, 1981]

\begin{tabular}{lll}
\hline Igeo & Igeo class & Contamination level \\
\hline$<0$ & 0 & Uncontaminated \\
$0<1$ & 1 & Uncontaminated - moderately contaminated \\
$1<2$ & 2 & Moderately \\
$2<3$ & 3 & Moderately - highly polluted \\
$3<4$ & 4 & Highly polluted \\
$4<5$ & 5 & Highly polluted - very highly polluted \\
$5<6$ & 6 & Very seriously polluted \\
\hline
\end{tabular}

The baseline value, $B_{n}$, of each heavy metal is the concentration of that element in average shale either directly measured from relatively presumed uncontaminated soil of the same texture or taken from the literature of a related work in that area. However, getting actual background concentration levels of most soils is questionable because of unquantifiable anthropogenic inputs of heavy metals over time
(Hamon et al, 2004). The table 4 shows geochemical index calculated using the Sample $\mathrm{C}$ being the experimental control value (EC) taken $100 \mathrm{~m}$ way from SFM dumpsite (relatively presumed uncontaminated soil of the same texture) and world shale average values (WSA) for the five metal considered in the study (Edori and Kpee 2017). 
Table 4. $\mathrm{I}_{\text {geo }}$ values using EC and WSA as $\mathrm{B}_{\mathrm{n}}$

\begin{tabular}{|c|c|c|c|c|c|}
\hline \multicolumn{6}{|c|}{$\mathbf{I}_{\mathrm{geo}}$ for SFM at Top $(\mathrm{Bn}=\mathrm{EC})$} \\
\hline $\begin{array}{l}\text { Heavy } \\
\text { Metal }\end{array}$ & $\begin{array}{l}H M \\
\text { Conc. }\end{array}$ & $B_{n}$ & $1.5 B_{n}$ & Conc/1.5Bn & $\operatorname{IgeO}=\log _{2}[\mathrm{Conc} / 1.5 \mathrm{Bn}]$ \\
\hline $\mathrm{Pb}$ & 0 & 0 & 0 & 0 & 0 \\
\hline $\mathrm{Fe}$ & 12.5 & 12.1 & 18.15 & 0.688705234 & -0.538041453 \\
\hline $\mathrm{Ni}$ & 0.2 & 0.28 & 0.42 & 0.476190476 & -1.070389328 \\
\hline $\mathrm{Cr}$ & 1.91 & 2.29 & 3.435 & 0.556040757 & -0.846737461 \\
\hline $\mathrm{Mn}$ & 1.25 & 0.85 & 1.275 & 0.980392157 & -0.028569152 \\
\hline \multicolumn{6}{|c|}{ Igeo for SFM at Top $(\mathrm{Bn}=\mathrm{WSA})$} \\
\hline $\begin{array}{l}\text { Heavy } \\
\text { Metal }\end{array}$ & $\begin{array}{l}H M \\
\text { Conc }\end{array}$ & $B n$ & $1.5 B n$ & Conc/1.5Bn & $\operatorname{IgeO}=\log _{2}[$ Conc/1.5Bn] \\
\hline $\mathrm{Pb}$ & 0 & 20 & 30 & 0 & 0 \\
\hline $\mathrm{Fe}$ & 12.5 & 47200 & 70800 & 0.000176554 & -12.46760555 \\
\hline $\mathrm{Ni}$ & 0.2 & 68 & 102 & 0.001960784 & -8.994353437 \\
\hline $\mathrm{Cr}$ & 1.91 & 90 & 135 & 0.014148148 & -6.143242959 \\
\hline $\mathrm{Mn}$ & 1.25 & 850 & 1275 & 0.000980392 & -9.994353437 \\
\hline
\end{tabular}

The Geo-accumulation, Igeo, evaluations showed that almost all the results are $<0$. The results belong to class I of the $\mathrm{I}_{\text {geo }}$ scale as given by Muller et al (1981). Results showing negative or $<0$ implies that there is no significant difference between the baseline concentration values $B_{n}$ and the accumulated concentration of that contaminant HM. Thus, there is no significant accumulated contamination in the metals considered at both the surface of the SFM and $100 \mathrm{~m}$ depth below the surface of the SFM (Alfred, et al. 2013). However, the $I_{\text {geo }}$ values calculated using the WSA values as the baseline concentrations, $B_{n}$, were lower since they had higher negative values. This is so because the $B_{n}$ values were higher than those from the $\mathrm{EC}$ values gotten from the research area.
Contamination Factor $C_{f}^{i}$ and Degree of contamination $C_{d}:$ The contamination Factor is a single element evaluation and thus it is given as;

$$
C_{f}^{i}=\frac{C_{o}^{i}}{C_{n}^{i}}
$$

Where; $C_{o}^{i}$ is the mean concentration of metals from least five sampling sites, and $C_{n}^{i}$ is the pre-industrial concentration of the individual element.

The $\mathrm{C}_{\mathrm{f}}$ is determined upon comparison with standard table of index established in figure 5. The Contamination Factor $\mathrm{C}_{\mathrm{f}}$, at the top of the SFM and $100 \mathrm{~cm}$ below the SFM were calculated using both the concentrations of the experimental control, EC, and the world shale average, WSA, concentration established as given in table 6 .

Table 5. Contamination factor, $C_{f}$ [Edori O.S. et al, 2017]

\begin{tabular}{ll}
\hline $\mathbf{C}_{\mathbf{f}}$ & Significance \\
\hline$<0.1$ & very slight contamination \\
$0.10-0.25$ & Slight contamination \\
$0.26-0.5$ & Moderate contamination \\
$0.51-0.75$ & Severe contamination \\
$0.76-1.00$ & Very severe contamination \\
$1.10-2.00$ & Slight pollution \\
$2.10-4.00$ & Moderate pollution \\
$4.1-8.0$ & Severe pollution \\
$8.1-16.0$ & Very severe pollution \\
$>16.0$ & Excessive pollution \\
\hline
\end{tabular}

Table 6. Contamination factor, $\mathrm{C}_{\mathrm{f}}$ at Surface and $100 \mathrm{~cm}$ depth

\begin{tabular}{|c|c|c|c|c|c|c|}
\hline $\begin{array}{c}\text { Heavy } \\
\text { Metal }\end{array}$ & Co & Cn-ctl & $C f=C o / C n$ & Co & $\begin{array}{l}\text { Cn- } \\
\text { wsa }\end{array}$ & $C f=C o / C n$ \\
\hline $\mathrm{Pb}$ & 0 & 0 & 0 & 0 & 20 & 0 \\
\hline $\mathrm{Fe}$ & 12.5 & 12.1 & 1.03305785 & 12.5 & 47200 & 0.0002648 \\
\hline $\mathrm{Ni}$ & 0.2 & 0.28 & 0.71428571 & 0.2 & 68 & 0.0029412 \\
\hline $\mathrm{Cr}$ & 1.91 & 2.29 & 0.83406114 & 1.91 & 90 & 0.0212222 \\
\hline $\mathrm{Mn}$ & 1.25 & 0.85 & 1.47058824 & 1.25 & 850 & 0.0014706 \\
\hline \multicolumn{7}{|c|}{ Contamination factor, $C_{f}$ at $100 \mathrm{~cm}$ depth } \\
\hline $\begin{array}{l}\text { Heavy } \\
\text { Metal }\end{array}$ & Co & $C n=c t r l$ & $C f=C o / C n$ & Co & $C n=w s a$ & $C f=C o / C n$ \\
\hline $\mathrm{Pb}$ & 0 & 0 & 0 & 0 & 20 & 0 \\
\hline $\mathrm{Fe}$ & 12.3 & 12.1 & 1.01652893 & 12.3 & 47200 & 0.0002606 \\
\hline $\mathrm{Ni}$ & 0.29 & 0.28 & 1.03571429 & 0.29 & 68 & 0.0042647 \\
\hline $\mathrm{Cr}$ & 2.14 & 2.29 & 0.93449782 & 2.14 & 90 & 0.0237778 \\
\hline $\mathrm{Mn}$ & 0.28 & 0.85 & 0.32941176 & 0.28 & 850 & 0.0003294 \\
\hline
\end{tabular}

Results of $\mathrm{C}_{\mathrm{f}}$ at the top of the SFM using WSA gave quite lower values compared to that of the EC. The $\mathrm{C}_{\mathrm{f}}$ obtained using the EC values revealed that no result was below 0.5 . The values for $\mathrm{Ni}$ and $\mathrm{Cr}$ had $\mathrm{C}_{\mathrm{f}}$ of 
0.714 and 0.834 respectively. This is categorized as Very Severe Contamination. Iron, Fe and Manganese Mn had $\mathrm{C}_{\mathrm{f}}$ of 1.039 and 1.471 respectively and are classified as Slight Pollution. The level of contamination of Iron $\mathrm{Fe}$ and Manganese $\mathrm{Mn}$ is not unconnected with the high concentration of these metals in underground water in the Niger Delta and particularly in Yenagoa environs [Agbalagba et al, 2011].

The Contamination factors, $\mathrm{C}_{\mathrm{f}}$, for the five metals studied at $100 \mathrm{~cm}$ depth of the SFM is given in table 6 . The results obtained using EC showed that Mn with 0.329 was classified as Moderate contamination. Ni, $\mathrm{Cr}$ and $\mathrm{Fe}$ with $\mathrm{C}_{\mathrm{f}}$ of $1.0357,0.9345$ and 1.0165 are classified as Very severe contamination.
The Degree of Contamination, $C_{d}$ is the sum of contamination factors for all five elements examined and is given as;

$$
C_{d}=\sum_{i=1}^{n} C_{f}^{i}
$$

The Contamination factors $\mathrm{C}_{\mathrm{f}}$ for the five element studied $[\mathrm{Pb}, \mathrm{Fe}, \mathrm{Ni}, \mathrm{Cr} \& \mathrm{Mn}]$ and the Degree of Contamination $\mathrm{C}_{\mathrm{d}}$ classes and terminologies is given in table 7 (Alfred, et al. 2013). The calculated values for the Degree of Contamination, $\mathbf{C}_{\mathbf{d}}$ for the five studied metals at the top of the SFM using the EC and WSA respectively is given in table 8a and 8.b.

\begin{tabular}{|c|c|c|}
\hline Cd Classes & \multicolumn{2}{|c|}{ Classes \& terminologies } \\
\hline$<8$ & \multicolumn{2}{|c|}{ Low contamination } \\
\hline$>8$ to $<16$ & \multicolumn{2}{|c|}{ Moderate contamination } \\
\hline$>16$ to $>32$ & \multicolumn{2}{|c|}{ considerable contamination } \\
\hline$>32$ & \multicolumn{2}{|c|}{ High contamination } \\
\hline \multicolumn{3}{|c|}{ Table 8. $C_{d}$ values at top of SFM and $100 \mathrm{~cm}$ depth } \\
\hline Heavy Metal & $C f=C o / C n-c t l$ & $C f=C o / C n-w s a$ \\
\hline $\mathrm{Pb}$ & 0 & 0 \\
\hline $\mathrm{Fe}$ & 1.033057851 & 0.000264831 \\
\hline $\mathrm{Ni}$ & 0.714285714 & 0.002941176 \\
\hline $\mathrm{Cr}$ & 0.834061135 & 0.021222222 \\
\hline $\mathrm{Mn}$ & 1.470588235 & 0.001470588 \\
\hline $\mathrm{Cd}=\sum \mathrm{Cf}$ & 4.051992936 & 0.025898817 \\
\hline \multicolumn{3}{|c|}{$C_{d}$ values at $100 \mathrm{~cm}$ depth of $S F M$} \\
\hline Heavy Metal & $C f=C o / C n-c t l$ & $C f=C o / C n-w s a$ \\
\hline $\mathrm{Pb}$ & 0 & 0 \\
\hline $\mathrm{Fe}$ & 1.016528926 & 0.000260593 \\
\hline $\mathrm{Ni}$ & 1.035714286 & 0.004264706 \\
\hline $\mathrm{Cr}$ & 0.934497817 & 0.023777778 \\
\hline $\mathrm{Mn}$ & 0.329411765 & 0.000329412 \\
\hline $\mathrm{Cd}=\sum \mathrm{Cf}$ & 3.316152793 & 0.028632489 \\
\hline
\end{tabular}

The results revealed that the $\mathrm{C}_{\mathrm{d}}$ value at the top of SFM dumpsite using WSA gave 0.02589 which is lower than the EC, which was 4.5199. However, both values of $\mathrm{C}_{\mathrm{d}}$ are lower than $8(<8)$ and are classified as class 1 with low contamination. The low contamination value implies that there was minimal contamination by the cumulative concentration of all the analysed heavy metals at the top of the SFM dumpsite. The Degree of Contamination $\mathrm{C}_{\mathrm{d}}$ at the top revealed a decrease in both baseline values [EC. WSA] from 4.05199 and 0.0258 to 3.316 and 0.0286 at $100 \mathrm{~cm}$ depth in SFM. Again the overall sum of the contamination factors $\sum \mathrm{C}_{\mathrm{f}}$ of all five elements called the $\mathrm{C}_{\mathrm{d}}$ was less than 8 $(<8)$ and is termed low contamination.

Modified Degree of Contamination mCd: This is the modified or generalised form of equation for the calculation of the modified degree of contamination, $\mathrm{mC}_{\mathrm{d}}$ for a given sampling site. It is given as;

$$
m C_{d}=\frac{\sum_{i=1}^{i=n} C_{f}^{i}}{n}
$$

Where, $\mathrm{n}=$ number of analysed elements; $C_{f}^{i}=$ Contamination Factor

Accordingly, the $\mathrm{mC}_{\mathrm{d}}$ for the five metals using the two scenarios of Cn-ctrl from experimental control and that of Cn-wsa from world shale average is calculated and compared to the standard index table for the $\mathrm{mC}_{\mathrm{d}}$ and their classes given in table 9. Calculated results of the $\mathrm{mC}_{\mathrm{d}}$ is given in table 10.0. The results showed that the $\mathrm{mC}_{\mathrm{d}}$ is lower for the calculated values using the world shale average, Cn-wsa being 0.005179 at the top 0.005726 at $100 \mathrm{~cm}$ depth as compared to calculated $\mathrm{mC}_{\mathrm{d}}$ values of 0.8104 at the top and 0.6632 at $100 \mathrm{~cm}$ depth of SFM from the experimental reference Cn-crl, However, the values of $\mathrm{mC}_{\mathrm{d}}$ using both reference cases were below the lowest class of contamination in the standard index. Therefore, the modified degree of contamination for the five metals in this study were less than 1.5 and are classified as very low degree of contamination. Pollution Load Index, PLI: The Pollution Load Index, PLI is used for detecting pollution which permits a comparison of pollution levels between sites and at different times. It enables 
or gives an estimate of the metal contamination status and the necessary action that should be taken. It is given in the equation below (Qingjie, et al. 2008);

$$
P L I=n \sqrt{c f_{1} \times c f_{2} \times \ldots \ldots \ldots c f_{n}}
$$

PLI $>=100$ indicates an immediate intervention. PLI $>=50$ indicates a more detailed study is required while a PLI $<50$ indicates that a drastic rectification measures were not needed.

Pollution Load Index, PLI at the Top for $\mathrm{Cn}=\mathrm{ctrl}$ and $\mathrm{Cn}=$ wsa are given in table 11 .

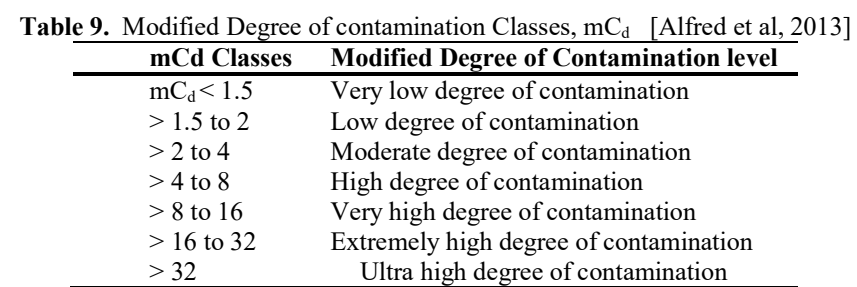

\begin{tabular}{lll}
\hline \multicolumn{4}{c}{ Table 10. $\mathrm{mC}_{\mathrm{d}}$ of Top and 100 $\mathrm{cm}$ in SFM } \\
\hline Sample area & $\sum \mathrm{C}_{\mathrm{f}}^{\mathrm{i}}$ & $\mathrm{mCd}=\sum \mathrm{C}_{\mathrm{f}}^{\mathrm{i}} / 5$ \\
\hline Top, $\mathrm{Cn}=\mathrm{ctrl}$ & 4.051992936 & 0.810398587 \\
$\mathrm{Top}, \mathrm{Cn}=$ wsa & 0.025898817 & 0.005179763 \\
$100 \mathrm{~cm}$ depth, $\mathrm{Cn}=\mathrm{ctrl}$ & 3.316152793 & 0.663230559 \\
$100 \mathrm{~cm}$ depth, $\mathrm{Cn}=$ wsa & 0.028632489 & 0.005726498 \\
\hline
\end{tabular}

Table 11. Pollution Load Index, PLI at the Surface and $100 \mathrm{~cm}$ depth of SFM

\begin{tabular}{|c|c|c|}
\hline Heavy metal & $\mathrm{Cf}=\mathrm{Co} / \mathrm{Cn}-\mathrm{ctl}$ & $\mathrm{Cf}=\mathrm{Co} / \mathrm{Cn}-\mathrm{wsa}$ \\
\hline $\mathrm{Pb}$ & 0 & 0 \\
\hline $\mathrm{Fe}$ & 1.033057851 & 0.000264831 \\
\hline $\mathrm{Ni}$ & 0.714285714 & 0.002941176 \\
\hline $\mathrm{Cr}$ & 0.834061135 & 0.021222222 \\
\hline $\mathrm{Mn}$ & 1.470588235 & 0.001470588 \\
\hline $\mathrm{Cf}_{1} \times \mathrm{Cf}_{2} \times \mathrm{Cf}_{3} \times \mathrm{Cf}_{4} \times \mathrm{Cf}_{5}$ & 0.905077105 & $2.43092 \mathrm{E}-11$ \\
\hline $\mathrm{PLI}=(\mathrm{x})^{1 / 5}$ & 0.980250598 & 0.007536231 \\
\hline \multicolumn{3}{|c|}{ Pollution Load Index, PLI at $100 \mathrm{~cm}$ depth in SFM } \\
\hline Heavy Metal & $\mathrm{Cf}=\mathrm{Co} / \mathrm{Cn}-\mathrm{ctl}$ & $\mathrm{Cf}=\mathrm{Co} / \mathrm{Cn}-\mathrm{wsa}$ \\
\hline $\mathrm{Pb}$ & 0 & 0 \\
\hline $\mathrm{Fe}$ & 1.016528926 & 0.000260593 \\
\hline $\mathrm{Ni}$ & 1.035714286 & 0.004264706 \\
\hline $\mathrm{Cr}$ & 0.934497817 & 0.023777778 \\
\hline Mn & 0.329411765 & 0.000329412 \\
\hline $\mathrm{Cf}_{1} \times \mathrm{Cf}_{2} \times \mathrm{Cf}_{3} \times \mathrm{Cf}_{4} \times \mathrm{Cf}_{5}$ & 0.324098562 & $8.70488 \mathrm{E}-12$ \\
\hline $\mathrm{PLI}=(\mathrm{x})^{1 / 5}$ & 0.798243555 & 0.006136949 \\
\hline
\end{tabular}

The PLI at the top of the SFM using the experimental control Cn-ctrl was 0.9802 and that using the world shale average Cn-swa was 0.00754 . Both results are less than the minimal pollution index scale of $<50$. Therefore, the top of the SFM was not polluted with the five metals analysed. Table 11 shows the PLI at $100 \mathrm{~m}$ in the SFM. The results showed that the PLI at $100 \mathrm{~m}$ in the SFM using the experimental control Cnctrl was 0.798 and that using the world shale average standard values was 0.00613 . These two values were both below the minimal pollution index of $<50$. This implies at $100 \mathrm{~m}$ in the SFM, there was no need for drastic remediation measure because there was minimal pollution at this point.

Conclusion: The investigation of the contamination and pollution level of selected five Heavy Metals [HMs] in spent Sand Filter Media [SFM] waste dumpsite revealed generally low total HMs concentrations with those at $100 \mathrm{~cm}$ depth, relatively lower, revealing that there was mobility of metal ions possibly due to leaching and chemical reactions. Generally, the concentrations were lower or within the permissible limits given by $\mathrm{WHO}$ and national standards with the trend; $\mathrm{Fe}>>>\mathrm{Cr}>\mathrm{Mn} \mathrm{Ni}>\mathrm{Pb}$ which agrees with high concentration of $\mathrm{Fe}$ in the underground water in this region. Geochemical Indices evaluation carried out using the world shale average (WSA) and the experimental control (EC) values revealed that for the Geoaccumulation Index, Igeo, there was no contamination. But the Contamination Factor, $\mathrm{C}_{\mathrm{f}}$, showed that was contamination at the top using EC values with slight pollution by $\mathrm{Fe}$ and $\mathrm{Mn}$ and at $100 \mathrm{~cm}$ depth, there was 'moderate contamination' from $\mathrm{Mn}$, while $\mathrm{Fe}, \mathrm{Cr}$, Ni were classified 'very severe contamination'. The Degree of contamination, $\mathrm{Cd}$, and Modified Degree of Contamination, $\mathrm{mCd}$, indices revealed 'low contamination'. The Pollution Load Index, PLI, index classified the dumpsite as 'requires no remediation measure' due to non-pollution at the time of this study. 
Acknowledgement: Ikoko is grateful to the Bayelsa State Ministry of Water Resources for granting me permission to complete a $\mathrm{PhD}$ programme

\section{REFERENCES}

Ademeroti, CMA (1996). Environmental Chemistry and Toxicology. March Prints and Consultancy.

Agbalagba, EO; Agbalagba, OH; Onunugbo, CP; Alao, AA (2011). Investigation into the Physicochemical Properties and Hydrochemical Processes of Groundwater from Commercial Boreholes In Yenagoa, Bayelsa State, Nigeria. Afr. J. Env. Sc. Tech. 5 (7): 473-481.

Alfred, SL; Khumoetsile, BM; Gilbert. KG (2013). Assessment of Heavy Metal Enrichment and Degree of Contamination around the CopperNickel Mine in the Selebi Phile Region. Eastern Botswana Env. Eco. Res. 1 (2): 32-40.

Amos-Tantua, BMW; Onigbinde, AO; Ere, D (2014). Assessment of some Heavy Metals and Physicochemical Properties in Surface Soils of Municipal Open Waste Dumpsite in Yenagoa, Nigeria." Afr. J. Env. Sc. Tech. 8 (1): 41-47.

APHA (1992). Standardd Methods for the Examination of Water and Wastewater. American Public Health Association.

Babagana, G; Bello, Z; Danrimi. B (2014). Impact Assessment of Heavy Metals Contamination of Ground Water in Mubi, Adamawa State, Nigeria. Int'l J. Sc. Env. Tech. 3 (6): 2120-2126.

Beltran, R; De la Rosa, JD; Santos, JC; Beltran, M; Gomez-Ariza, JL (2010). Heavy metal mobility assessment in sediments from the Odiel River (Iberian Pyritic Belt) using sequential extraction. Env. Earth Sc. J. (Springer Verlag) 61: 14931502.

Cakmakci, M; Koyuncu, I; Kinaci, C (2009). Effects of Iron Concentrations, Filter Hydraulic Loading Rates, and Porosities on Iron Removal by Rapid Sand Filtration. Env. Engr. Sc. (Marry Ann Liebert Inc) 25 (5): 669-676.

Cotruvo, JJ; Fawell, JK; Giddings, M; Jackson, P; Magara, HY; Festo-Ngowi, AV; Ohanian, E (2011). Pb in Drinking Water: WHO Guidelines for Drinking Water. In Background doc. for the dev. of WHO Guidelines for Drinking Water Quality, 1-15

Du, J; Contruvo, JJ; Fawell, JK; Giddings, M; Jackson, P; Magara, YH; Ngow-Festo, AV; Ohanian, E
(2011). Mn in Drinking Water: WHO Guidelines for Drinking Water Quality. Vol. 1, Background doc. dev. of WHO guidelines for Drinking Water Quality, 1-15

Dube, AR; Zhytniewski, TK; Cukrowska, E; Buszewski, B (2001). Adsorption and Migration of Heavy Metals in Soil. Polish J. Env. Studies 10 (1): $1-10$.

Fawell, JK; Lund, U; Mintz, B (2003). Fe in Drinking Water: WHO Guidelines for Drinking Water Quality. Vol. 2, in Background Doc. for the dev. of WHO Guidelines for Drinking Water Quality. WHO report.

Fawell, JK; Contruvo, JJ; Giddings, M; Jackson, P; Magara, H; Festo-Ngowi, AV; Ohanian, E (2007). Ni in Drinking Water: Background document for development of $\mathrm{WHO}$ Guidelines for drinking water quality. Background Doc. for Dev. of Drinking Water Quality, WHO Report. 1-16.

Hamon RE; McLaughlin MJ, Gilkes RJ, Rate AW, Zarcinas AR, Cozens G, Radford N, Betteney L (2004) Geochemical indices allow estimation of heavy metal background concentration in soils. Global Biochemical Cycle. 18(Gb1014): 1-6

Horsfall, M Jnr (2014). Fundamental Principles of Analytical Chemistry. First. Port-Harcourt: Soteria Publishing House.

Leizou, KE; Horsfall, M Jnr; Spiff, AI (2015). Speciation of Some Heavy Metals in Sediments of the Pennington River, Bayelsa State, Nigeria. American Chem. Sc. J. (Science Domain International) 5 (3): 238-246.

Li, X; Feng, L (2012). Geostatistical analyses and fractionation of heavy metals in urban soil from industrial district in Weinan, NW China. Env. Earth Sc. J. (Springer Verlag 2012) 67: 21292140 .

Lynn, TJ; Wanjugi, P; Harwood, VJ; Ergas, SJ (2013). Dynamic performance of biosand filters. $J$. Am Water Works Ass, E587-E595.

Muller, G (1981). The Heavy Metal Pollution of the Sediments of Neckars and it's Tributary: A stocktaking. Chemikar Zitung. J. of Environmental Protection. 5(14) 205-164

Mustafa, S; Yusuf, MI (2012). A textbook of Hydrology and Water Resources. Topsmerit Page Publishing Company. p337-378 
Qingjie, G; Jun, D; Yunchuan, X; Qingfei, W; Liqiang, Y (2008). Calculating Pollution Indices by Heavy Metals in Ecological Geochemistry Assessment and a Case Study in Parks of Beijing. J. Chin Univ. of Geosc. 19 (3): 230-241.

Sielechi, JM; Kayem, GJ; Sandu. I (2010). Effect of Water Treatment Residuals (Almunium and Iron ions) on Human Health and Drinking Water Distribution Systems. Int'l J. Conservation Sc. 1 (3): 175-182.
Stoddart, AK; Gagnon. GA (2015). Full-Scale Prechlorine Removal: Impact on Filter Performance and Water Quality. J. Am. Water Works Ass. 107 (12): E638-E647.

World Health Organisation (2011). Guidelines for Drinking Water Quality 4th ed. Geneva: WHO Library Cataloguing-in-PublicationData

Wu, Z; He, M; Lin, C (2012). Environmental impacts of heavy metals $(\mathrm{Co}, \mathrm{Cu}, \mathrm{Pb}, \mathrm{Zn})$ in surficial sediments of estuary in Daliao River and Yingkou Bay (northeast China): concentration level and chemical fraction. Env. Earth Sc. J., 66, 24172430 